\title{
Redesain Interior Gedung Pusat Unggulan Iptek Sistem dan Kontrol Otomotif Sebagai Sarana Riset dan Edukasi Dengan Konsep Futuristik
}

\author{
Agista Maulidiya Rochmah, Mahendra Wardhana dan Thomas Ari Kristianto \\ Jurusan Desain Produk Industri, Fakultas Teknik Sipil dan Perencanaan, Institut Teknologi Sepuluh \\ Nopember (ITS) \\ Jl. Arief Rahman Hakim, Surabaya 60111 Indonesia \\ e-mail: mahendra.interior@gmail.com
}

\begin{abstract}
Abstrak-PUI-SKO (Pusat Unggulan Iptek bidang Sistem Kontrol Otomotif) merupakan pusat riset dan inovasi yang memfokuskan pada topik efisiensi energi kendaraan konvensional dan pengembangan teknologi pada kendaraan listrik. Pada tanggal 14 Desember 2015 Pusat Studi Energi ITS ditetapkan sebagai Pusat Unggulan Iptek bidang Sistem dan Kontrol Otomotif berdasarkan SK Menristekdikti Nomor: 553/M/Kp/XXI/2015 tentang litbang yang dibina sebagai Pusat Unggulan Iptek tahun 2016 - 2018 [1] dengan syarat pemenuhan kondisi pada eksisting sesuai dengan Key Performance Indicator (KPI) dari Pusat Unggulan Iptek. Dalam hal ini perancangan ulang interior dapat membantu meningkatkan Key Performance Indicator (KPI) yang telah ditetapkan untuk menjadi lembaga riset bertaraf internasional yang dimiliki oleh ITS - Indonesia.

Perancangan ulang interior PUI - SKO yaitu pada 3 area (Showroom \& Lobby, Ruang Prototype \& Lab Komputer, Office). Tahapan pengumpulan data dimulai dari observasi objek desain, wawancara kepala pusat riset / anggota pusat riset, dan analisa melalui kuisioner. Berdasarkan metodologi desain diatas, hasil yang diperoleh untuk perancangan ulang interior PUI SKO berupa penambahan sarana edukasi dan konsep langgam futuristik. Sarana edukasi merupakan fasilitas yang memiliki tujuan untuk dapat menyampaikan informasi dari PUI-SKO kepada masyarakat secara mudah melalui desain. Penyampaian edukasi menggunakan media furniture hingga elemen estetis yang interaktif dan teknologi untuk meningkatkan semangat pengunjung dalam memperoleh informasi otomotif dari PUI SKO. Konsep futuristik merupakan suatu langgam desain yang mencerminkan simbol teknologi, yang selalu berkembang ke masa depan. Pengaplikasian bentuk dari futuristik yang menarik menjadi poin utama pada area yang dilalui oleh pengunjung, dan dapat memberikan semangat baru pada tim PUI-SKO.

Dengan konsep perancangan ulang Interior PUI - SKO diatas diharapkan dapat meningkatkan kualitas pusat riset menjadi unggul di Indonesia, dan mendapat perhatian masyarakat mengenai produk ramah lingkungan yang diciptakan oleh anak bangsa Indonesia.
\end{abstract}

Kata kunci : Desain Interior, Edukasi, Futuristik, Pusat Unggulan Iptek, Sistem dan Kontrol Otomotif, PUI-SKO, Research center

\section{PENDAHULUAN}

$\mathrm{L}$ aboratorium Sistem dan Otomasi Industri ITS adalah satu - satunya laboraturium di Indonesia dengan fasilitas riset yang lengkap. Mulai dari peralatan uji mobil dan motor listrik, composite fabrication, $3 D$ scanner, $3 D$ photogravimetry, peralatan fabrikasi komponen, fasilitas desain teknik dan reverse engineering, uji coba sistem kontrol, hingga sistem komputer mobil terintegrasi. Pemanfaatan fasilitas - fasilitas terebut telah menghasilkan lebih dari 5 produk penelitian dibidang sistem dan kontrol otomotif dibawah koordinasi Pusat Studi Energi LPPM - ITS. Selama empat tahun Laboratorium Otomasi Industri berlokasi di gedung Teknik Mesin FTI ITS hingga pada tahun 2015, Pusat riset Mobil Listrik ITS didirikan dengan misi sebagai pengembangan laboratorium otomasi industri dengan tujuan meriset mobil-mobil dan segala hal yang berkaitan dengan sistem dan kontrol otomotif.

Produk/ karya / hasil riset yang telah diproduksi masal oleh Laboraturium Sistem dan Otomasi Industri ITS yaitu Engine Controller Unit (ECU) Iquteche, adalah sebuah alat cerdas yang dapat mengatur jalannya mesin sepeda motor pada berbagai kondisi dan beban. Keberhasilan ini mendapat apresiasi dari kementrian Riset Dikti pada tahun 2015 dalam penghargaan inovasi Indonesia. Laboratorium Sistem dan Otomasi Industri ITS juga memfasilitasi pelaksanaan riset Mobil Listrik Nasional (MOLINA) dibawah tanggung jawab studi Energi LPPM - ITS berdasarkan SK Rektor di tahun 2013, 2014, 2015 yang menghasilkan mobil listrik Lowo Ireng Super Car, Electric Solar Bus, Ezzy 1 dan Ezzy 2, Sepeda motor listrik dan Braja Wahana dengan spesifikasi bobot lebih ringan dan diperkirakan bisa melaju hingga kecepatan 200 km/jam lebih tinggi dari seri Ezzy. Tidak hanya ECU Iquteche dan Molina saja, Pengembangkan mobil bertenaga surya juga dilakuakn pada laboratorium ini, seperti seri Widyawahana 4 dan 5 jugal Sapu Angin dimana telah memberikan beberapa penghargaan untuk ITS salah satu penghargaan terbarunya yaitu meraih juara pertama dalam kompetisi mobil hemat bahan bakar, "Shell Eco Marathon Challenge Asia (SEMA) 2016" di Filipina.

Pada tanggal 14 Desember 2015 Pusat Studi Energi ITS ditetapkan sebagai Pusat Unggulan Iptek Sistem dan Kontrol Otomotif berdasarkan SK Menristekdikti Nomor: 553/M/Kp/XXI/2015 tentang lembaga litbang yang dibina sebagai Pusat Unggulan Iptek tahun 2016 - 2018 dengan syarat pemenuhan kondisi pada eksisting sesuai dengan Key Performance Indicator (KPI) (seperti pada Tabel 1.1) untuk menjadi Pusat Unggulan IPTEK Sistem dan Kontrol Otomotif. 


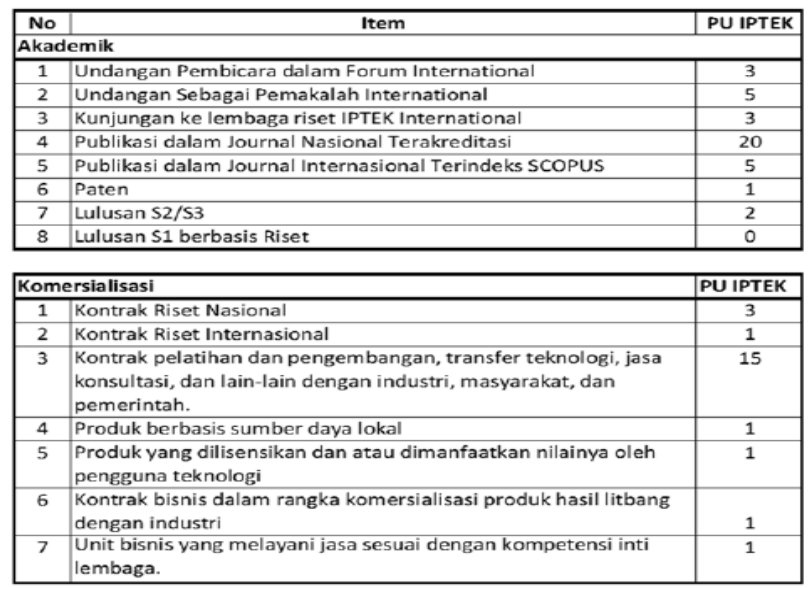

Tabel 1. Perbandingan KPI sisi akademik antara kondisi eksisting dengan kondisi yang diharapkan pada PUI

Beberapa data eksisting yang telah memenuhi syarat Key Performance Indicator (KPI) akan ditingkatkan lebih baik lagi sesuai standar internasional dan juga berlaku untuk data yang belum dicapai seperti tabel bidang academic excellence, publikasi dan lulusan S2 dan S3 akan tetap dicapai dengan beriringan sebagai lembaga baru dari Pusat Unggulan Iptek Sistem dan Kontrol Otomotif.

Melihat banyak potensi diatas, perancangan ulang interior bangunan laboratorium Sistem dan Otomasi Industri ITS dapat mempengaruhi dalam mencapai target dari Key Performance Indicator (KPI) dengan menyediakan fasilitas ruang yang lebih bermanfaat dan sesuai kebutuhan lembaga.

\section{A. Permasalahan}

- Bagaimana menampilkan corporate image Institut Teknologi Sepuluh Nopember pada interior didalam ruangan sebagai perguruan tinggi yang terpilih menjalankan PUI - Sistem dan Kontrol Otomotif?

- Bagaimana mendesain ruangan yang dapat memberikan kepuasan, baik untuk pengunjung atau pengguna fasilitas riset?

- Bagaimana menciptakan desain interior pusat riset yang memberikan dampak pada kinerja anggota dari PUI Sistem dan Kontrol Otomotif?

- Bagaimana menciptakan desain interior pusat riset yang dapat membantu meningkatkan target Key Performane Indicator PUI - Sistem dan Kontrol Otomotif?

\section{B. Batasan Masalah}

Desain interior difokuskan pada beberapa ruang terpilih yang mewakili gambaran dari Gedung Pusat Unggulan Iptek (PUI) Sistem dan Kontrol Otomotif yang meliputi Showroom (Ruang Display Mobil atau karya dari gedung Pusat Unggulan Iptek - Sistem dan Kontrol Otomotif) dan lobby, Area kerja kegiatan riset (Ruang Prototype, Ruang Lab), Area Office. Desain tidak menghilangkan tatanan kolom struktur pada bangunan eksisting Gedung PUI Sistem dan Kontrol Otomotif.

\section{Tujuan}

- Mendesain interior untuk mempresentasikan PUI Sistem dan Kontrol Otomotif dan Teknologi Sepuluh Nopember Surabaya kepada masyarakat.

- Mendesain interior pusat riset dengan sebuah konsep yang matang. Memadukan langgam futuristik dan edukasi, serta menciptakan desain interior interaktif untuk lebih mudah menyampaikan langusung kepada masyarakat.

- Mendesain untuk memecahkan permasalahan layout gedung PUI - Sistem dan Kontrol Otomotif sehingga mendapatkan sirkulasi yang sesuai dan nyaman; material aman dan perabotan yang ergonomi diesuaikan kegiatan yang ada didalam Gedung PUI- Sistem dan Kontrol Otomotif.

- Merancang faslitas tambahan yang yang dibutuhkan pada kegiatan yang belum dicapai didalam tabel KPI PUI - Sistem dan Kontrol Otomotif.

\section{Manfaat}

- Memberikan kenyamanan interior bagi pengunjung, calon lulusan S2 / S3 dan anggota PUI - Sistem dan Kontrol Otomotif

- Menunjukkan sebuah image instansi dan visi sebagai bentuk komunikasi.

- Memberikan kesan dan pengalaman tersendiri setelah melihat desain interior yang nyaman dan interaktif sehingga masyarakat merasa ingin berkunjung kembali.

- Mendukung untuk menyampaikan wujud nyata kemampuan mahasiswa ITS dengan memberikan desain interior yang informatif.

- Membentuk opini pengunjung untuk lebih mencintai dan menghargai produk otomotif Indonesia.

\section{URAIAN PENELITIAN}

\section{A. Metode Pengumpulan Data}

Desain interior pada PUI - Sistem dan Kontrol Otomotif ini telah melakukan tahap pengumpulan data melalui beberapa metode pengumpulan data, yaitu pengumpulan data secara langsung dan tidak langsung. Pengumpulan data secara langsung dapat dilakukan dengan cara observasi pada objek desain yang dituju, serta kuisioner kepada pengunjung dari objek desain. Pengumpulan data secara tidak langsung yaitu dilakukan dengan mengumpulkan data dari berbagai literatur seperti buku, jurnal ilmiah dan internet.

Dalam tahap pengumpulan data, dilakukan beberapa tahapan, diantaranya sebagai berikut:

\section{Observasi Lapangan}

Metode observasi dilakukan dengan mengunjungi langsung lokasi dari PUI - Sistem dan Kontrol Otomotif dan mengetahui secara langsung interior serta segmentasi pengunjungnya.

2. Kuisioner

Metode kuisioner ini ditujukan kepada pengunjung dari PUI - Sistem dan Kontrol Otomotif 


\section{Studi Literatur}

Metode kepustakaan (Studi Literatur) ini merupakan metode pengumpulan data yang memanfaatkan buku, literatur maupun internet sebagai bahan referensi untuk memperoleh kesimpulan atau pendapat para ahli dengan mendapatkan kesimpulan tersebut sebagai metode tersendiri.

\section{Studi Pembanding}

Studi pembanding dilakukan untuk mendapatkan data pembanding yang bermanfaat sebagai referensi dalam redesain PUI - Sistem dan Kontrol Otomotif

\section{B. Metode Analisis Data}

Metode yang digunakan penulis dalam perancangan ini adalah metode analitis, yaitu metode yang menganalisa kembali setiap hal perancangan. Metode analitis yang digunakan yaitu metode analisa deskriptif. Menurut Sugiyono (2004:169) [2] Analisis deskriptif adalah statistik yang digunakan untuk menganalisa data dengan cara mendeskripsikan atau menggambarkan data yang telah terkumpul sebagaimana adanya tanpa bermaksud membuat kesimpulan yang berlaku untuk umum atau generalisasi. Metode ini digunakan dalam proses analisa data yang didapat melalui survey ataupun wawancara kepada pengunjung langsung serta diikuti dengan kuisionerkuisioner.

\section{Metode Desain}

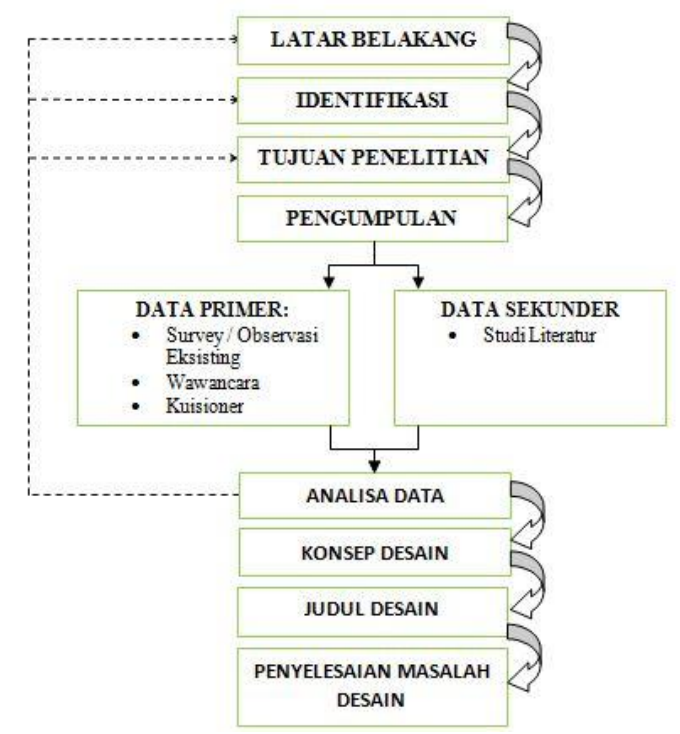

Gambar 2. Proses Desain

\section{PEMBAHASAN}

\section{A. Objek Desain}

Objek desain yang diambil adalah Gedung Pusat Unggulan Iptek Sistem dan Kontrol Otomotif - ITS Surabaya yang terletak pada Gedung Riset Mobil Listrik Institut Teknologi Sepuluh Nopember (ITS) Keputih sukolilo Surabaya 60111 Jawa Timur, Indonesia
PUI-SKO (Pusat Unggulan Iptek bidang Sistem Kontrol Otomotif) merupakan lembaga pengembangan dari tim peneliti Mobil Listrik Nasional dan beberapa peneliti dari berbagai jurusan di ITS. Lembaga ini bergerak dibawah koordinasi wakil rektor bidang kerjasama, penelitian dan inovasi.

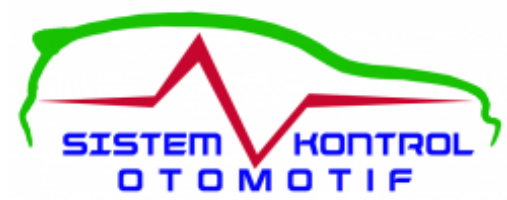

Gambar 3. Logo PUI - Sistem dan Kontrol Otomotif

Pada desain akan ditampilkan bentuk- bentuk yang berkaitan dengan logo PUI - Sistem dan Kontrol Otomotif.

\section{B. Konsep Makro}

Desain interior Gedung PUI - Sistem dan Kontrol Otomotif memiliki konsep futuristik yang edukatif sehingga pengunjung dan pengguna dapat berinteraksi langsung dan mendapatkan informasi / pengetahuan mengenai otomotif yang berkaitan dengan konsep PUI - Sistem dan Kontrol Otomotif.

Konsep Futuristik diperoleh dari pertimbangan visi dan misi dari PUI - SKO dan ITS dimana memiliki visi dan misi yang sama. Selain itu pertimbangan diperoleh dari analisa kuisioner dan wawancara hingga mendapatkan langgam futuristik sebagai konsep utama dalam gaya desain ruangan

Konsep lainnya adalah fun, dimana konsep ini untuk mendukung kenyamanan aktifitas di dalam ruangan. Konsep ini selaras dengan pendapat M. Wardhana (2015) dan contoh penerapan konsep fun pada bentuk interior sebagaimana Dr. Adityara dan M. Wardhana (2016).

\section{Konsep Mikro}

1. Futuristik

Konsep Futuristik diperoleh dari pertimbangan visi dan misi dari PUI - SKO dan ITS dimana memiliki visi dan misi yang sama. Selain itu pertimbangan diperoleh dari analisa kuisioner dan wawancara hingga mendapatkan langgam futuristik sebagai konsep utama dalam gaya desain ruangan.

\section{Edukatif}

Konsep edukatif yaitu ingin mendesain suatu ruangan yang tidak hanya indah atau nyaman juga memberikan iformasi - informasi otomotif yang mudah dipahami oleh pengunjung ataupun pengguna. Selain itu terdapat pada visi misi yang dimiliki ITS maupun PUI - SKO dalam hal pendidikan teknologi dan penelitian. Edukasi juga ditunjukkan dari alur kerja yang ada didalam PUI. Alur kerja dan aktivitas seperti ini selaras dengan yang dikemukakan M Wardhana (2016:101 - 106).

\section{Konsep Mikro}

\section{Dinding}

Pengaplikasian konsep utama desain pada dinding ialah dengan matte finish putih dan pada area tertentu terdapat glossy. Warna monokrom digunakan dengan harapan dapat membuat ruangan terasa netral sehingga 
pengunjung akan tlebih banyak fokus pada koleksi museum.

Pada dinding tertentu terdapat informasi mengenai PUI - SKO baik dalam informasi mengenai corporate, produk riset hingga beberapa informasi yang memberikan tambahan ilmu dalam hal teknologi mobil masa depan.

\section{Lantai}

Lantai yang digunakan tidak terlalu banyak bentukan yang rumit hanya menggunakan permainan material hingga permainan penataan arah keramik. Terdapat konsep patern yang difungsikan sebagai elemen estetis dan juga sebagai pemenuh ruangan sehingga tidak terlihat sepi.Teksture tile lebih pada glossy, doff, tampilan concrete. Warna utama yang digunakan adalah warna monokrom abu - abu dan putih. Terdapat permainan lantai seperti terdapat art yang menampilkan lantai terkena efek drift dari mobil namun diolah sedemikian rupa menyesuaikan dengan konsep / gaya yang digunakan yaitu futuristik.

\section{Plafond}

- Plafon pada konsep Futuristik sebagian diekspose yang mana memperlihatkan material ekpose dengan konsep concrete dan plafond menggunakan material elastic plafond yang memiliki keuntungan dalam pemasangan, perawatan, dan dapat dibentuk sesuka hati karena karakter materialnya yang elastis.

- hanging plafond juga memiliki fungsi elem estetis dengan tujuan membuat pengunjung tertarik untuk menuju pada area tersebut.

- konsep dinding menerus hingga ke plafond.

\section{Furnitur}

Konsep furniture pada gaya Futuristik lebih pada bentuk yang abstrak, unik atau streamline tetapi tetap terlihat simple dan modern. Material yang digunakan seperti Suede atau kulit atau material kayu, stainless steel, batu, acrylic.

\section{Elemen Estetis}

Konsep elemen estetis pada gaya Futuristik lebih pada permainan dinding dengan bentuk streamline dengan konsep cahaya hidden lamp. Bentuk yang digunakan diambil dari transformasi bentuk yang diambil dari gabungan bagian logo ITS dengan PUISKO.

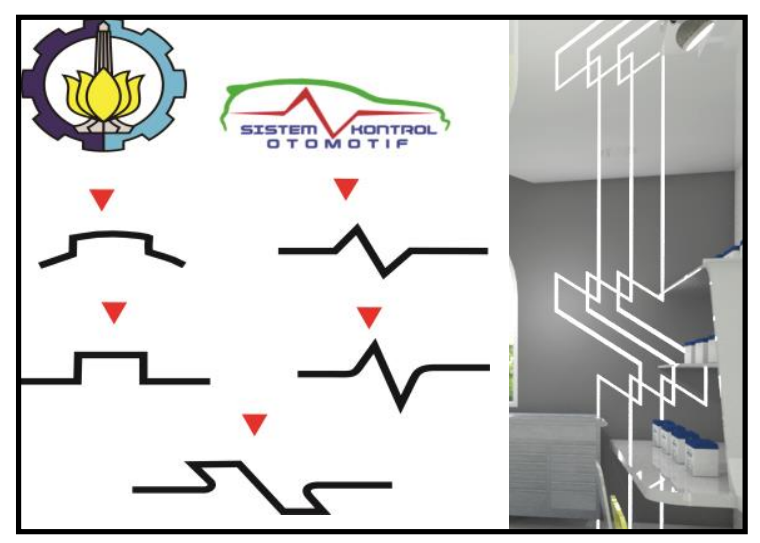

Gambar 4. Transformasi Bentuk Logo PUI - SKO dan ITS

E. Ruang Terpilih 1 - Area Lobby dan Area Pamer / Showroom

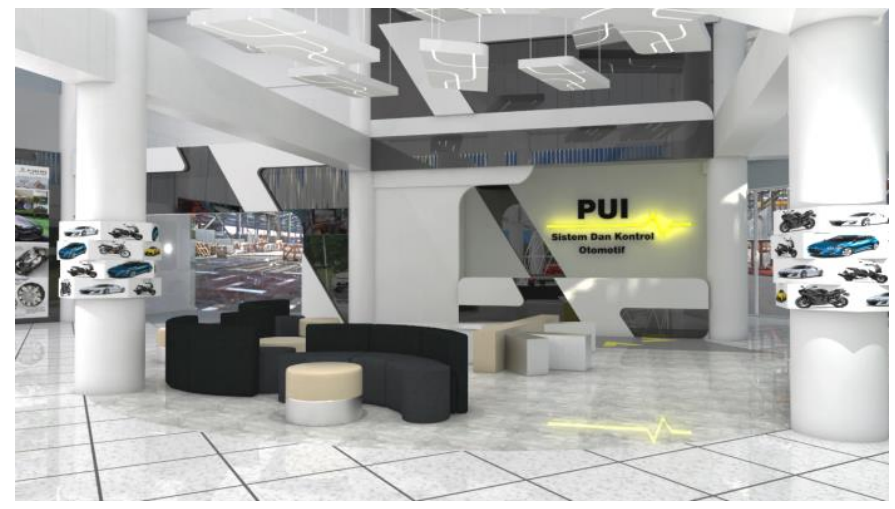

Gambar 5. Ruang Lobby dan Area Pamer View 1

Permainan hanging plafond langsung mengarahkan kita ke arah resepsionis memfokuskan kita langsung melihat ke arah logo PUI pada backdrop yang menjadi point of interest ketika baru memasuki area lobby. Melakukan pengulangan pola yang ada pada lantai untuk lebih menyatukan desain satu sama lain.

Menggunakan pencahayaan hidden lamp pada elemen estetis di dinding sehingga memberikan efek dramatis pada area tersebut dan mempertegas bentukan - bentukan tersebut agar dapat dilihat.

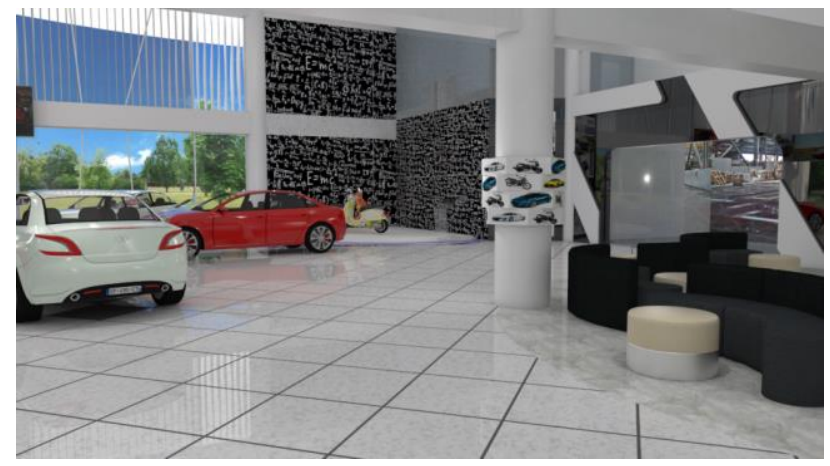

Gambar 6. Ruang Lobby dan Area Pamer View 2 
View2 dari area yang mendisplay motor elektrik terbaru yaitu GESITS dengan konsep background terdapat coretan coretan rumus yang dijadikan wall art.

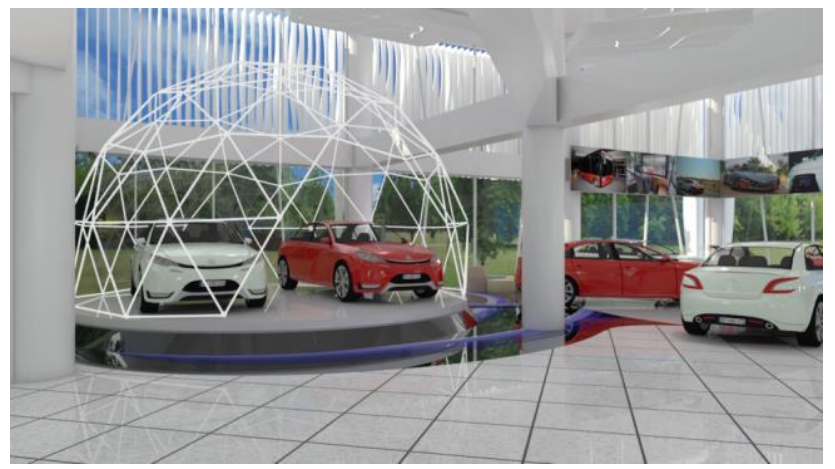

Gambar 7. Ruang Lobby dan Area Pamer View 3

Terdapat perbedaan leveling untuk membedakan antara area pamer dan area sirkulasi pengunjung. Sehingga tetap ada batasan antara pengunjung dan produk yang dipamerkan.

\section{F. Ruang Terpilih 2 - Ruang Prototype dan Ruang lab}

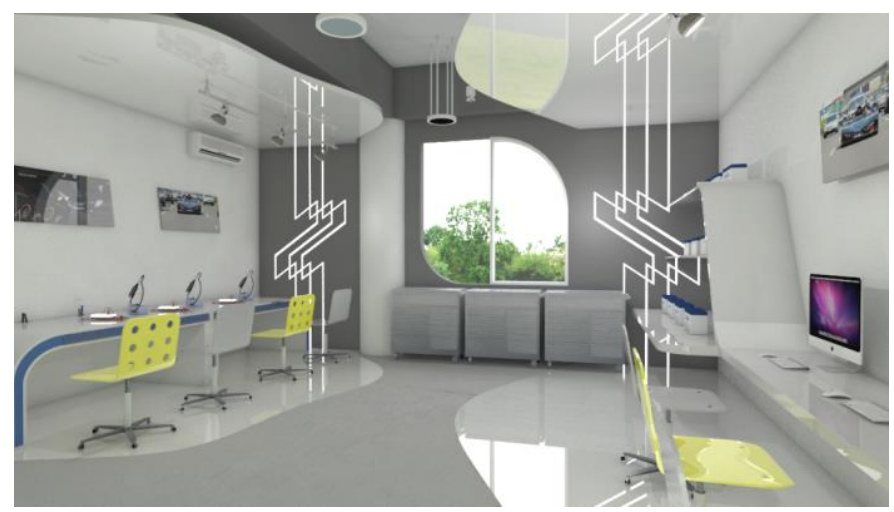

Gambar 8. Ruang Prototype View 1

Penggunaan material utama pada ruangan ini adalah concrete, HPL, glossy dan matte finish (cat). Furniture yang digunakan menggunakan konsep simple dan futuristik dengan material hpl glossy.

Konsep warna putih diterapkan untuk menciptakan suasana bersih dimana area solder atau perakitan identik dengan kotor dan berantakan. Penyediaan furniture rak ditujukan agar para pengguna dapat menata dengan rapi kembali setelah bekerja dan hasil kerja dapat didisplay rapi dimana kerapian berdampak pada kinerja dan perawatannya.

Pada dinding terdapat hidden lamp yang diletakkan didalam dinding concrette sebagai elemen estetis ruangan. Bentuk line hidden lamp menggunakan hasil dari transformasi bentuk yang telah dijabarkan pada Gambar 7.

Konsep pola lantai dan plafond memberikan pembeda disetiap area didalam ruangan yaitu antara area kerja, area penyimpanan dan sirkulasi.

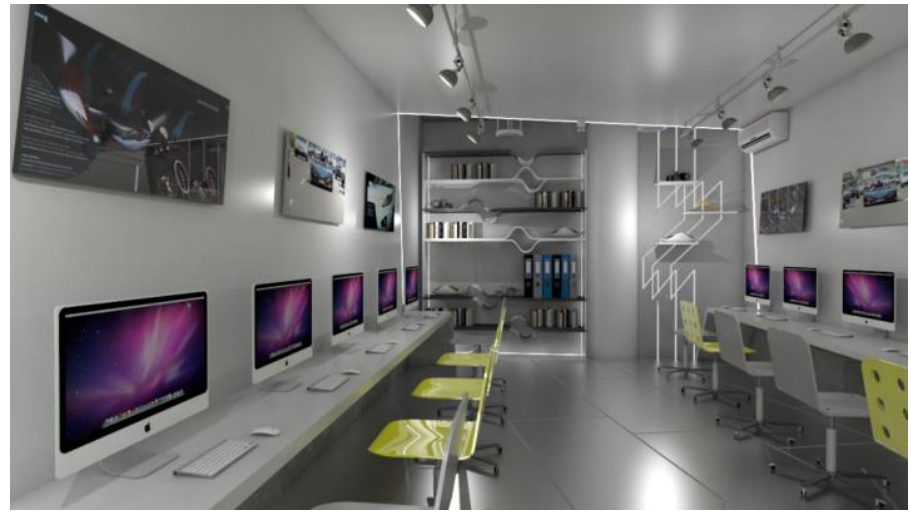

Gambar 9. Ruang Lab View 2

Ruang lab PUI - Sistem dan Kontrol Otomotif. Desain interior ruangan ini tidak jauh berbeda dengan konsep ruang prototype yaitu dengan konsep concrete dan HPL. Pada ruangan ini menggunakan konsep warna putih dengan banyak penggunaan bentukan - bentukan dari transformasi bentuk logo PUI dan ITS.

Meja kerja didesain untuk mensiasati ruangan yang tidak terlalu besar dengan konsep bentukan miring dan menerus hingga ke plafond sehingga menghasilkan karakter dari konsep futuristik itu sendiri.

Penggunaan hidden lamp juga diberikan pada ruang lab sebagai mempertegas furnitur dan elemen estetis pada ruang tersebut. Pada gambar diatas hidden lamp digunakan pada rak, dinding dan plafond. Warna kuning kursi diambil dari warna di logo ITS maupun PUI - Sistem dan Kontrol Otomotif. karena konsep futuristik tidak terlalu menggunakan banyak warna namun lebih pada ke bentukan dan fungsional.

Penggunaan lampu spot selain untuk elemen estetis juga sebagai penambah cahaya apabila cahaya general masih kurang terang, dan dapat di arahkan pada meja kerja langsung.

\section{G. Ruang Terpilih 3 - Ruang Kantor}

Ruangan view untuk area kantor PUI - SKO ketika berada di lantai 2. Pada lantai mengkombinasikan material glossy dan concret glossy dengan pola bentuk futuristik. Area kantor mengankan konsep openspace karena permintaan dari kepala PUI - SKO sendiri ingin tidak ada batasan antara atasan dan pegawai sehingga dapat bercengkrama secara leluasa, namun untuk mensiasati tetap meruang yaitu dengan penggunaan partisi yang juga berfungsi sebagai rak, Sehingga memberikan kesan batasan yang tidak dipaksakan pada area tersebut.

Material utama yang ada pada area kantor PUI - Sistem dan Kontrol Otomotif yaitu concrete, HPL, acrylic, dan kaca. Pembeda area juga dilakukan dengan permainan bentuk pola lantai dan plafond. 


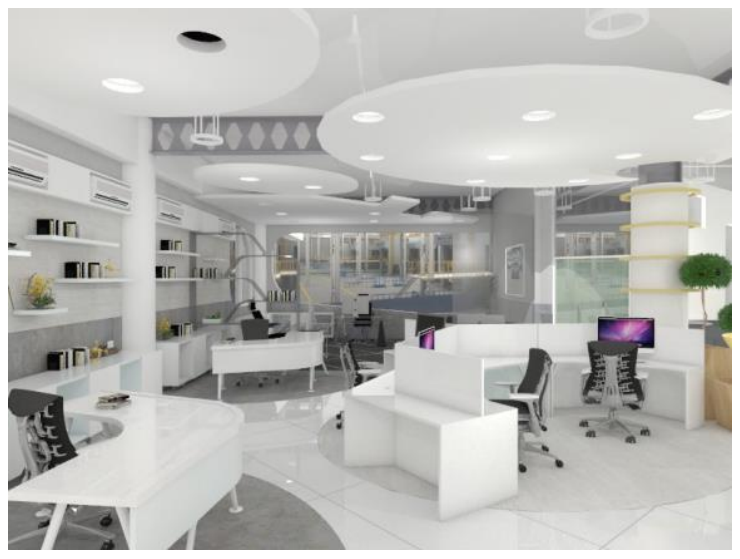

Gambar 10. Ruang Kantor View 1

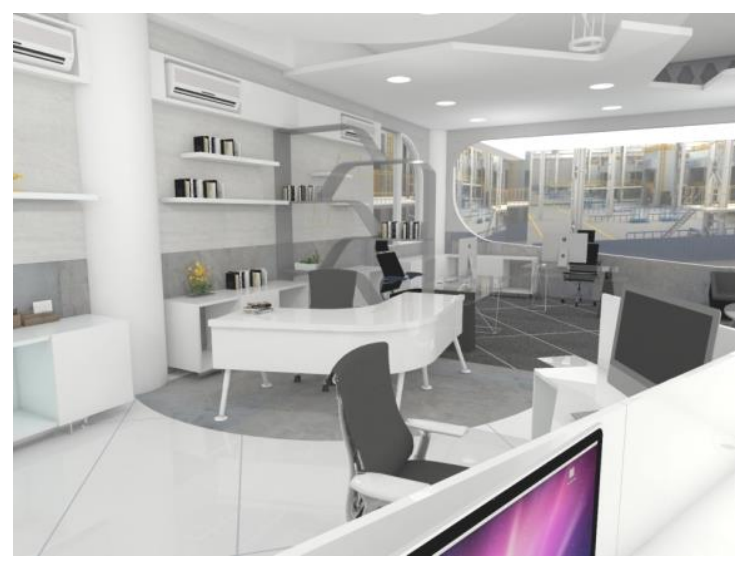

Gambar 11. Ruang Kantor View 2

Pada view ini ingin memperlihatkan konsep dinding yang terdapat rak melayang dan hidden lamp yang ada pada dinding. Hidden lamp menjadi aksen tersendiri pada ruangan sehingga memberikan kesan ruangan yang berkarakter mengingat bentukan lampu menyesuaikan transformasi bentuk yang sudah dibuat.

\section{KESIMPULAN}

Dari pembahasan mengenai Redesain Interior Gedung Pusat Unggulan Iptek Sistem dan Kontrol Otomotif dapat disimpulkan beberapa hal, antara lain:

a. Perubahan litbang dari Gedung MOLINA menjadi Gedung Pusat Unggulan Iptek Sistem dan Kontrol otomotif menjadi alasan utama perlunya perancangan ulang / desain ulang interior bangunan sesuai visi dan misi terbaru dari PUI.

b. Beragam kebutuhan di dalam Lobby dan area pamer / showroom berpotensi untuk penambahan fasilitas yang menunjang dalam menyampaikan edukasi ataupun memperkenalkan PUI - Sistem dan Kontrol Otomotif kepada masyarakat luas.

c. Perancangan ruang yang baik mulai dari sirkulasi hingga furniture yang ergonomi dengan menyesuaikan kegiatan PUI - Sistem dan Kontrol Otomotif dapat membantu dalam memberikan efisiensi waktu dan tenaga sehingga produk - produk riset dapat dihasilkan lebih banyak lagi.

d. Menampilkan interior yang menarik dan menyediakan fasilitas tambahan sesuai visi dan misi dari PUI Sistem dan Kontrol Otomotif dengan konsep futuristik yang berorientasi ke masa depan dengan dasar teknologi (sesuai visi dan misi dari PUI - SKO) diharapkan dapat memberikan kontribusi besar dalam hal teknologi dan riset otomotif.

\section{DAFTAR PUSTAKA}

[1] Republik Indonesia. 2015. SK Menristekdikti Nomor: 553/M/Kp/XXI/2015 tentang litbang yang dibina sebagai Pusat Unggulan Iptek tahun 2016 - 2018. Serketariat Negara. Jakarta.

[2] Sugiyono. (2004). Metode Penelitian Administrasi.Alfabeta: Bandung 